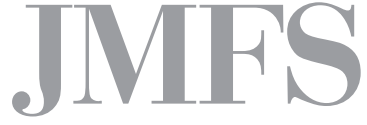

Journal of Management and Financial Sciences
Volume XI

Issue 32 (June 2018)

pp. 71-82

Warsaw School of Economics

Collegium of Management and Finance

Krystian Barłożewski

Collegium of Management and Finance

SGH Warsaw School of Economics

\title{
Is Foreign Expansion an Effective Way to Boost Sales and Profits?
}

\begin{abstract}
This paper posits, based on the data set covering an 8-year period between 2006 and 2013, that Polish firms show an inverted U-curve relationship between multinationality and performance. At the beginning of internationalization a short stage of rising performance might be observed, however, quickly rising costs stemming from the liability of newness and foreignness lead to a fall in performance. This is not only contrary to the predictions resulting from the traditional S-curve analysis but also indicates that executives' high expectations regarding foreign expansion might be a sign of a "global illusion".
\end{abstract}

Keywords: internationalization, performance, M-P relationship JEL Classification Codes: F23, M16 


\section{Introduction}

International expansion is commonly considered as a way for further firms' growth and as a measure to secure their long-term sustainability or even survival. It becomes an especially important issue in the light of decreasing possibilities of significantly improving firms' financial performance when staying solely in the local market. From the managerial perspective, going abroad in such a situation may seem the only remaining solution. Hence an obvious question arises as to whether increasing multinationality leads to a superior performance.

Despite a growing amount of empirical research, the findings on the Multinationality-Performance (MP) linkage have been inconsistent and often described as contradictory, confusing, mixed or unsatisfactory [Bausch, Krist, 2007, p. 320]. Thus, multinationality of the firm and its performance remains a primary research subject in international business research focused on explaining what are the gains and costs from international expansions, how to measure them best and what are the internal and external factors moderating returns from multinationality [Griffith, Cavusgil, 2008, pp. 1126-1228].

As much of the entire literature on MP linkage relates to the advanced countries, it is proposed to focus more attention on the developing countries as their significance in the world economy is steadily growing [Assaf et al., 2012, p. 202; Rugman, Oh, 2011, p. 204]. This line of reasoning justifies the discussion about the influence of multinationality on firms' performance in Central and East European countries like Poland. It seems that this subject represents a promising venue of research as that topic has been present in the Polish literature only for a few years, which warrants further studies in that area [Karasiewicz, 2013, pp. 179, 234].

This paper contributes to the advancement of the literature by testing longitudinally the MP relationship for Polish public companies over an 8-year period between 2006 and 2013, i.e. entirely after the accession of Poland to the European Union. The article is constructed as follows. In the first section the previous empirical results on the MP linkage, including Polish, were elaborated on with potential rationale for their existence. The second section presents the conceptual framework, data used for the study and hypotheses to be tested. The third part of the article is devoted to the discussion of the result received. And finally, conclusions from the research accompanied by managerial recommendations were put forward.

\section{Shape of the MP relationship}

Initially research studies examined whether firms expanding abroad achieved better performance than firms operating exclusively in their home markets. Subsequently, more focus was gained by the attempts to verify how performance related to the changes in the degree of multinationality [Verbeke, Brugman, 2009, p. 266]. The views on that matter have evolved 
over years and, as it was mentioned before, the received empirical results still preclude scholars from drawing unequivocal conclusions.

First, it was expected to find a simple positive linear fit between multinationality and performance. It was argued that benefits of internationalization (including economies of scale and scope, risk diversification, learning from distant locations, exploitation of differences in factor markets, etc.), would dominate potential costs [Rugman, Oh, 2010, p. 483]. In subsequent years that view was questioned and the negative linear MP linkage was also tested [Matysiak, Bausch, 2007, p. 198]. Its proponents reasoned that after reaching some point costs arising from the liability of newness, liability of foreignness, complexity of foreign operations, as well as costs of product adaptation to local demands, foreign exchange costs and others would outweigh the potential benefits derived from international expansion [Li, 2007, pp. 120-121]. It turned out, though, that the third option was also found whereby there is no significant MP relation [Sullivan, 1994, p. 328].

Since the $1990 \mathrm{~s}$ the benefits and costs of foreign expansion have been verified more closely and new $\mathrm{U}$-curve and inverted $\mathrm{U}$-curve shapes have been introduced [Annavarluja, Beldona, 2000, p. 55]. The first curve stresses the importance of learning in foreign markets as it may help to increase the benefits and reduce the costs arising at the inception phase of internationalization [Ruigrok, Wagner, 2004, p. 6]. According to Contractor the U-curveshape is most likely to occur in the developing countries and young industries where only a small fraction of firms managed to achieve a high level of internationalization [Contractor, 2007, p. 468].

The inverted U-curve shape should in turn accentuate the stage of over-internationalization, where the increased costs of expansion outweigh additional benefits. This might be explained by growing costs of coordinating foreign operations; entering new markets with lower potential; increasing cultural, geographical, legal and language differences or by deteriorating competitive advantages used abroad, which leads to falling performance [Li, 2007, p. 121; Glaum, Oesterle, 2007, p. 309].

To reconcile the conflicting results both curves have been combined and a new S-curve relationship with three stages was proposed [Contractor, Kundu, Hsu, 2003, pp. 6-7]. The first stage of early internationalization refers to the dominating liability of newness and foreignness over the initial benefits from expanding abroad. The second stage reflects the reaped scale economies and learning effect likely to occur after some point is exceeded. The last stage exhibits the costs arising from over-internationalization and decreasing benefits. It should be noted that the S-relation was observed earlier in the $1990 \mathrm{~s}$ but without any valid theoretical rationale provided [Riahi-Belkaoui, 1998, pp. 316-319].

Sometimes an inverted S-curve relationship is identified whereby in the first short period performance is improving, then in the second phase remaining at the similar lever or decreasing. Occasionally at high multinationality levels a significant improvement of performance may be observed. More recently an M-curve relationship has been proposed to explain performance changes of INVs (International New Ventures), i.e. young firms which started internationalization from their inception. It extends the $\mathrm{S}$-curve and assumes that there is one more initial 
stage at very low levels of multinationality, where INVs achieve net performance gains thanks to entering foreign markets [Lee, 2010, p. 4].

The last proposition is an inverted M-curve which together with the M-curve shape are used by Almodovar in his research on the moderating influence of product strategies. He posits that the $\mathrm{M}$-curve relates well to firms adopting a strategy of product standardization and the inverted $\mathrm{M}$-shape is observed for firms following product customization strategies. It is argued that in the first case firms recognizing a business opportunity abroad do not have to introduce significant changes to capture them effectively, which in turn leads to a profitable sales increase. This stage is called "global illusion", as firms start to expand further into foreign markets, which is linked with an increasing liability of foreignness. The further internationalization path follows then according to the traditional S-curve relationship [Almodovar, 2012, pp. 307-312].

\section{Empirical results in the Polish literature}

A comprehensive review of the extant Polish literature made by the author shows that there is quite a large number of papers examining the performance of internationalizing vs local firms but only a handful of articles testing sensu stricto the MP relationship. Similarly, as in the international literature, the empirical results in Table 1 also seem to be conflicting or at least inconsistent.

Table 1. Relation between multinationality and performance in Polish research papers

\begin{tabular}{|l|c|}
\hline \multicolumn{1}{|c|}{ Shape of relationship } & Times occurred \\
\hline Multinational firms gain better results than domestic firms & 10 \\
\hline Positive linear (implicitly or explicitly) & 9 \\
\hline U-curve & 6 \\
\hline No difference in performance between multinational and domestic firms & 3 \\
\hline Inverted U-curve & 2 \\
\hline No relation found & 2 \\
\hline S-curve & 1 \\
\hline J-curve & 1 \\
\hline Linear negative & 1 \\
\hline
\end{tabular}

Note: There were in total 127 papers issued between 2006 and 2014 included into the analysis.

Source: K. Barłożewski, 2017. Wplyw ekspansji zagranicznej na efektywność przedsiębiorstw. Warszawa: Wydawnictwo C.H. Beck.

Despite significant differences in results it seems that a general conclusion may be drawn that multinationality generally leads to better results than focusing solely on the local market. Usually it is explained by a set of benefits which may be derived from expanding abroad including a firm's greater flexibility, risk diversification, a firm's enhanced image, acquired knowledge and skills and economies of scale [Wach, 2012, pp. 123-125, 200-201]. 
Based on Table 1, a U-relation also enjoys a significant popularity among Polish scholars. They suggest that the first stage of decreasing performance may be due to a relatively low level of internationalization of Polish firms, which implies a lack of necessary knowledge; a focus on competing with low prices not quality and also due to highly intensive competition in European markets [Karasiewicz, 2013, pp. 320-321]. Others argue that with accumulated business experience eventually firms achieve a point of inflection where benefits from internationalization start to dominate potential costs [Ratajczak-Mrozek et al., 2012, pp. 219-220]. It is worth, however, noting that some researchers were not sure what cost-benefit trade-offs to expect and tested multiple curves for the MP relationship. Based on this line of reasoning, the following hypothesis for a long-term effect may be formulated: "There exists a U-curve relationship between multinationality and performance of Polish firms".

\section{Data sources}

The study uses the data on 97 Polish public companies with grounded foreign activities between 2006 and 2013. As data on foreign activities, including foreign sales of Polish companies is not easily available for public or academic purposes, if at all, I had to apply a twostages approach to design and develop a dedicated database for further use. The first firmlevel financial data was collected from the downloaded annual reports and other documents issued by all Polish firms listed on the Warsaw Stock Exchange for the period covered. The database created contains 335 companies. Among those companies a sample was compiled of 143 firms with $\min .5 \%$ of total sales revenues received in other countries for the last 3 years covered in the analysis.

In the second stage, the primary survey data on 97 firms from the sample of 143 was collected using the mix mode CATI+CAWI method (Computer Assisted Telephone Interviewing + Computer Assisted Web Interviews). The questionnaire consisted of questions relating to geographical regions served, experience gained abroad, entry modes and motives of internationalization. The survey was conducted under the author's supervision by Indicator, an external research agency.

The data gathered at both stages has been subsequently merged and as a result a data set containing 97 firms and 682 observations was built.

\section{Dependent variables}

There are four types of performance measures used in the study as dependent variables. These are Return on Equity (ROE), Return on Assets (ROA), Return on Sales (ROS) and sales growth. 
The measures are based on the following calculation formulas. ROE is calculated as net profits to equity, ROA as net profits to total assets, ROS as net profit to total revenue from sales and sales growth as a percentage change in annual total revenues from sales.

All of them are accounting measures most often used in the research of the MP relationship mainly due to easy access to data and because they are commonly accepted in research [Verbeke, Brugman, 2009, p. 270; Glaum, Oesterle, 2007, p. 312]. ROE allows for analyzing firms' total performance and comparing return on investment in different types of firms. It is also suggested that ROE reflects whether a firm is able to continue its operations in the long term [Sokołowska, 2012, p. 46]. ROA determines a firm's overall capability to generate profit by using its assets [Sierpińska, T. Jachna, 2004, pp. 196-202]. ROS represents the relation of price levels to costs incurred and hence a capability of making profit. Sales growth in turn illustrates a firm's growth in terms of revenue.

\section{Independent variables}

The major explanatory variable used in this study is the degree of internationalization calculated as the ratio of foreign sales to total sales (FSTS). It is underlined by other authors that this measure is very limited in scope, captures only one dimension of multinationality and thus may present a distorted view of firms' advancement in foreign operations [Sullivan, 1994, pp. 327-330, 338]. However, as FSTS is frequently used by scholars [Yang, Driffield, 2012, p. 26], sometimes even recommended until a better measure is designed and developed [Rugman, Oh, 2011, p. 203] and due to a very limited access to other data that measure was introduced to the analysis.

\section{Control and moderating variables}

One moderating and nine control variables have been defined and controlled for in the analysis to neutralize influences of economy-level, firm-level, industry-level and time components in the regression equations as these could distort yielded empirical findings.

The only moderating variable are internationalization motives. They were incorporated into the analysis using dummy variables representing market-seeking, efficiency-seeking, competitiveness related and political-institutional internationalization motives. For each of those motives a firm-level compound index has been designed and calculated (Cronbach alfa greater than 0.5). It represents the importance of a particular motive for a given company. Subsequently - regarding each motive -the sample was divided into two subsets with a low and high value of the index. Based on that, adequate values for dummy variables were assigned. 
Entry modes of internationalization are also controlled for using dummy variables. There are two major categories distinguished - nonequity modes of entry (mainly exporting) and equity ventures (FDI). The third control variable was a firm's size - a medium-sized vs large company. The latter was defined based on the following criteria (consistent with the criteria applied in Polish law): more than 250 employees, annual sales revenue exceed PLN 200 mio. (ca. EUR 50 mio.) and total assets exceed PLN 172 mio. (ca. EUR 43 mio.). The size effect was also controlled for by introducing dummy variables.

The fourth variable was a firm's age, which was controlled for by dummy variables representing young firms (equal to or below 12 years) and old firms (above 12 years). The fifth variable was a firm's industry - construction, heavy, light, IT and advanced technologies, trade and services industries - which was also controlled for by dummy variables. The sixth variable is geographical diversification, which represents the number of regions (out of 7) in which a given company is present. The seventh control variable is international experience also reflected by dummy variables relating to the four categories: (1) expansion began before 1989, (2) expansion began between 1989 and 1999, (3) expansion began between 2000 and Poland's EU accession and (4) expansion took place first after Poland joined the EU. The eighth control variable related to the overall economic condition, which was reflected by the real GDP change in Poland. Additionally, to eliminate autocorrelation problems, the last ninth control variable was introduced to measure the time of the observations, whereas the observations from 2006 were assigned with the value of one, the observations from 2007 with value of two and so on, ending with eight for 2013.

\section{Specification of the econometric model}

To test the hypothesis put forward in the previous section a multiple linear regression analysis was employed. Based on the discussion presented in the previous section, the regression equation to be estimated is as follows:

$$
\begin{aligned}
\text { PERF }_{\mathrm{i}} & =\beta_{1}+\beta_{2} \text { FSTS }_{i}+\beta_{3}\left(\text { FSTS }_{i}^{2}+\beta_{4}\left(\text { FSTS }_{i}^{3}+\sum \beta_{m} \text { Motives }_{m, i}+\right.\right. \\
& \left.+\beta_{m f} \text { Motives }_{m, i} * \text { FSTS }_{i}\right)+\sum \beta_{c} \text { Controlvariables }_{c i}
\end{aligned}
$$

where PERF is the performance of $i$ company in the sample, FSTS $\mathrm{i}_{\mathrm{i}}$ represents the degree of

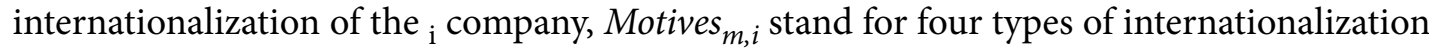
motives of the icompany, Control variables represent the nine control variables defined above. Although a U-curve relationship was expected, linear and cubic shapes of the MP linkage were also tested to gain deeper insight into the empirical findings. 


\section{Results and discussion}

The results of the regression analysis are reported in Table 2. It was found out that the MP relationship fits an inverted U-shape curve for all the dependent variables except from ROE. The linear and cubic curves were not supported at all, hence they were excluded from Table 2.

Table 2. Results of the regression analysis for the MP relationship

\begin{tabular}{|c|c|c|c|c|}
\hline Independent variables & ROE & $\mathrm{ROA}$ & ROS & Sales growth \\
\hline Intercept & $-1.724^{\star \star}$ & $-0.774^{\star \star}$ & $-0.753^{\star \star}$ & $-3.692^{\star \star}$ \\
\hline Year & $-0.010 * \star$ & $-0.004^{\star \star}$ & -0.002 & $-0.010^{\star}$ \\
\hline FSTS & 0.015 & $-0.029 * \star$ & $-0.021^{\star}$ & $-0.049 \dagger$ \\
\hline$(\mathrm{FSTS}) \wedge 2$ & 0.004 & $-0.007^{\star \star}$ & $-0.005^{\star}$ & $-0.012 \dagger$ \\
\hline Company size & 0.019 & $0.014^{*}$ & $0.013 \dagger$ & $0.083^{* *}$ \\
\hline Company age & $0.049 *$ & $0.020 \dagger$ & 0.013 & 0.010 \\
\hline Geographical diversification & $0.007 \dagger$ & $0.006^{\star *}$ & $0.008^{* *}$ & -0.003 \\
\hline Expansion between 1989 and 1999(1) & -0.008 & -0.007 & -0.005 & -0.012 \\
\hline Expansion between 2000 and EU accession (1) & -0.025 & $-0.022^{*}$ & $-0.021 \dagger$ & -0.034 \\
\hline Expansion after Poland's EU accession (1) & $-0.072^{\star \star}$ & $-0.038^{\star \star}$ & $-0.026^{\star}$ & -0.007 \\
\hline Construction industry (2) & $0.038 \dagger$ & 0.000 & -0.001 & -0.027 \\
\hline Light industry (2) & $0.052^{*}$ & $0.020^{*}$ & 0.013 & 0.019 \\
\hline Trade and services (2) & $0.062^{*}$ & 0.004 & -0.003 & $0.068^{*}$ \\
\hline Advanced technologies industry (2) & 0.009 & 0.001 & 0.01 & 0.002 \\
\hline Real GDP change in EU-15 countries & $0.018 * *$ & $0.008 * *$ & $0.007 * *$ & $0.037^{* *}$ \\
\hline Equity entry modes (3) & -0.033 & -0.004 & 0.030 & 0.047 \\
\hline Non-equity and equity entry modes (3) & -0.009 & 0.000 & 0.01 & 0.005 \\
\hline Market-seeking motives & -0.008 & $-0.013 \dagger$ & 0.003 & 0.010 \\
\hline Competitiveness-related motives & 0.019 & $0.015^{\star}$ & 0.008 & -0.024 \\
\hline Efficiency-seeking motives & $-0.038^{*}$ & $-0.020^{*}$ & $-0.015 \dagger$ & -0.008 \\
\hline Political and institutional motives & -0.026 & $-0.019 *$ & $-0.02^{\star}$ & -0.019 \\
\hline Market-seeking motives * FSTS & -0.003 & -0.005 & -0.002 & -0.012 \\
\hline Competitiveness-related motives * FSTS & $0.024^{\star \star}$ & 0.000 & -0.005 & 0.016 \\
\hline Efficiency-seeking motives * FSTS & 0.006 & $0.012^{* *}$ & $0.007^{*}$ & -0.012 \\
\hline Political and institutional motives * FSTS & -0.002 & 0.000 & 0.000 & $0.022^{*}$ \\
\hline $\mathrm{R}^{2}$ & $15.5 \%$ & $19.4 \%$ & $14.9 \%$ & $20.4 \%$ \\
\hline$R^{2}$ adj. & $12.1 \%$ & $16.2 \%$ & $11.5 \%$ & $17.0 \%$ \\
\hline $\mathrm{F}$ & $4.617^{\star *}$ & $6.026^{* *}$ & $4.327^{\star \star}$ & $5.959 * \star$ \\
\hline \multicolumn{5}{|l|}{ Significance levels: ${ }^{* *} p<0.01 ;{ }^{*} p<0.05 ; \uparrow p<0.1$} \\
\hline \multicolumn{5}{|c|}{ (1) Benchmark values relate to "Expansion before 1989" } \\
\hline \multicolumn{5}{|l|}{ (2) Benchmark values relate to "Heavy industry" } \\
\hline (3) Benchmark values relate to "Non-equity entry & & & & \\
\hline
\end{tabular}

Source: the author's own elaboration. 
The size effect measured by adjusted $\mathrm{R}^{2}$ was ranging between $11.5 \%$ and $17.0 \%$ and might be considered as moderate. It is worth noting that the received values were higher than in other Polish research studies on the MP relation [Doryń, Stachera, 2008, p. 97; Karasiewicz, 2013, pp. 270-273]. This might be partially explained by a larger set of control variables included into the analysis.

However, only a few control variables provided evidence for a significant effect, including company size, geographical diversification, starting expansion after the EU accession of Poland and the real GDP change in EU-15 countries. First, the findings suggest that larger companies achieve better financial performance than smaller firms, which confirms the analysis in the previous sections. In the case of Polish companies it should be explained by the access to larger resources and years of experience accumulated in the international arena.

Figure 1. The MP relationship for ROA

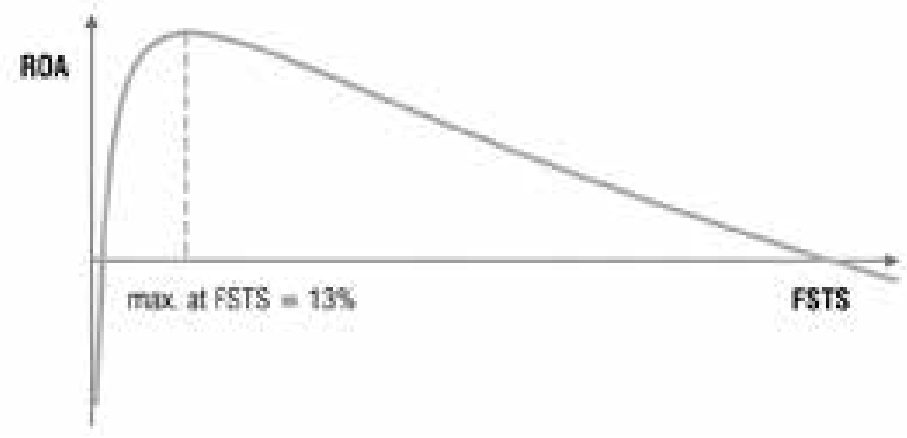

Source: the author's own elaboration.

The data shows that bigger firms entered foreign markets much sooner than their smaller counterparts. Secondly, the results for geographical diversification suggest that firms operating in a larger number of markets achieve higher profitability of assets and sales. This may lead to a conclusion that geographical diversification may reduce total risk.

Thirdly, firms with the lowest experience i.e. which started foreign expansion after Poland acceded the EU exhibited significantly lower results than other companies. Fourthly, a very significant control variable was the real change in GDP of EU-15 countries, which are the main exporting partners of Polish firms.

Fifthly, companies guided by efficiency-seeking or political-institutional motives of internationalization generally achieved weaker financial results than companies for which those motives were not significant during expansion. The findings for efficiency-seeking motives may be explained by higher costs arising from the liability of newness and foreignness compared to potential savings achieved through deployment of operations across borders. The results for political and institutional motives may be in turn explained by the willingness of the analyzed firms to establish new activities in more mature and stable markets, which may be linked with more intensive competition and lower margins. 
As to the received shape of the MP linkage, it should be stated that the empirical findings are contrary to the theoretical predictions, as primarily a standard U-relation was expected. Here it can be argued that results are more in line with the recently proposed $\mathrm{M}$-curve as the inverted U-curve may represent the initial short stage of "global illusion" and the subsequent stage of falling performance due to arising liabilities of foreignness and newness. This idea seems to be additionally supported by the shape of the plot in Figure 1.

The curves of the identified MP relationships for ROA, ROS and sales growth are quite similar in their shapes. For that reason only one curve for the ROA measure was presented in Figure 1. Depending on the variable, the maximum point is achieved at FSTS equal to ca. 13\%.

\section{Summary}

In contrast to the international literature, the relationship between the degree of multinationality and performance is a relatively new venue of research in the extant body of Polish literature as there is only a handful of papers devoted sensu stricto to that topic. This paper contributes to the advancement of the MP relationship analysis two-fold. Firstly, a longitudinal analysis covering an 8-year period entirely after the EU accession of Poland (between 2006 and 2013) was conducted, which, according to the author's best knowledge, is the first such attempt. This gave a strong support for an inverted U-shape MP relationship, which in turn proves to be contrary to the theoretical predictions based upon commonly adopted S-curve in the advanced economies. The empirical findings seem to confirm the "global illusion" effect discussed in the recently proposed M-curve.

Secondly, a large set of contextual variables was incorporated into the analysis and moderating effect of motives of internationalization was examined as well. The latter was strongly recommended by other scholars to be included, as it might have a strong impact on results. It turned out, however, that the motives of going abroad do not show a strong and reproducible influence on firms' performance. Among control variables tested, a significant effect was observed for company size, international experience, geographical diversification into dissimilar markets and general economic conditions measured by the percentage change of real GDP. This may lead to a conclusion that the contextual nature of the MP relationship may be related only to a limited set of variables, which still need to be identified and their influence to be explained. 


\section{References}

1. Almodovar P, 2012. The international performance of standardizing and customizing Spanish firm. The M curve relationships. Multinational Business Review, Vol. 20, No. 4.

2. Annavarluja M., \&Beldona S., 2000. Multinationality-Performance: A Review and Reconceptualization. International Journal of Organizational Analysis, Vol. 8, No. 1.

3. Assaf A.G., Josiassen A., Ratchford B.T., \& Barros, C.P., 2012. Internationalization and Performance of Retail Firms: A Bayesian Dynamic Model. Journal of Retailing, Vol. 88, No. 2.

4. Barłożewski K., 2017. Wpływ ekspansji zagranicznej na efektywność przedsiębiorstw [Impact of internationalization on Firms' Performance]. Warszawa: Wydawnictwo C.H. Beck.

5. Bausch A., \& Krist M., 2007. The Effect of Context Related Moderators on the Internationalization-Performance Relationships: Evidence from Meta Analysis. Management International Review, Vol. 47, No. 3.

6. Contractor F.J., 2007. Is international business good for companies? The evolutionary or multistage theory of internationalization vs. the transaction cost perspective. Focused issue on internationalization and firm performance. Management International Review, Vol. 47, No. 3.

7. Contractor F.J., Kundu S.K., \& Hsu, Ch.-Ch., 2003. A three-stage theory of international expansion: the link between multinationality and performance in the service sector. Journal of International Business Studies, Vol. 34, No. 1.

8. Dörrenbächer Ch., 2000. Measuring corporate internationalisation: A review of measurement concepts and their use. Intereconomics, Vol. 35, Issue 3.

9. Doryń W., \& Stachera D., 2008. Wpływ internacjonalizacji na wyniki ekonomiczne największych polskich przedsiębiorstw przemysłowych. Gospodarka Narodowa, No. 11-12.

10. Glaum M., \& Oesterle M.-J., 2007. 40 Years of Research on Internationalization and Firm Performance: More Questions than Answers? Management International Review, Vol. 47, No. 3.

11. Griffith D. A, Cavusgil S.T., \& Xu, S., 2008. Emerging themes in international business research. Journal of International Business Studies, Vol. 39, No. 7.

12. Karasiewicz G., 2013. Marketingowe strategie internacjonalizacji polskich przedsiębiorstw. Podejście holistyczne. Warszawa: Oficyna a Wolters Kluwer Business.

13. Lee I.H., 2010. The M curve: the performance of born-regional firms from Korea. Multinational Business Review, Vol. 18, No. 4.

14. Li L., 2007. Multinationality and Performance: A Synthetic Review and Research Agenda. International Journal of Management Reviews, Vol. 9, Issue 2.

15. Matysiak L., \& Bausch A., 2012. Antecedents of MNE performance: blinded by the obvious in 35 years of literature. Multinational Business Review, Vol. 20, No. 2.

16. Riahi-Belkaoui A., 1998. The effects of the degree of internationalization on firm performance. International Business Review, Vol. 7.

17. Rugman A.M., \& Oh Ch.H., 2011. Methodological issues in the measurement of multinationality of US firms. The Multinational Business Review, Vol. 19, No. 3.

18. Ruigrok W., \& Wagner H., 2004. Internationalization and firm performance: Meta-analytic review and future research directions. University of St. Gallen: Working Paper. 
19. Sierpińska M., \& Jachna T., 2004. Ocena przedsiębiorstwa według standardów światowych, Warszawa: PWN.

20. Sullivan D., 1994. Measuring the Degree of Internationalization of a Firm. Journal of International Business Studies, Vol. 25, No. 2.

21. Verbeke A., \& Brugman P., 2009. Triple-testing the Quality of Multinationality-Performance Research: An Internalization Theory Perspective. International Business Review, Vol. 18, Issue 3.

22. Wach K., 2012. Europeizacja małych iśrednich przedsiębiorstw: rozwój przez umiędzynarodowienie. Warszawa: Wydawnictwo Naukowe PWN.

23. Yang Y., \& Driffield N., 2012. Multinationality-Performance Relationship. A Meta-analysis, Management International Review, Vol. 52. 